\title{
The human rights responsibilities of multinational tobacco companies
}

\section{E Crow}

Tobacco Control 2005;14(Suppl II):ii14-ii18. doi: 10.1136/tc.2004.009027

This article explores various strategies which could be used to hold the tobacco industry accountable for human rights violations precipitated by its conduct. First, a brief overview of the international human rights regime and the tobacco related jurisprudence issued by human rights treaty bodies is provided. The article then explains how tobacco control advocates could promote more systematic consideration of governments' tobacco related human rights violations by reconceptualising the Framework Convention on Tobacco Control in the language of rights. The feasibility of using the existing human rights framework to target the tobacco industry directly is analysed with the conclusion that this approach has serious limitations. Emerging human rights norms, which have greater potential to affect the industry's conduct, are presented. Finally, given the questionable authoritativeness of these norms, alternative ways that they could be employed to hold tobacco companies accountable for the rights related consequences of their activities are proposed.

Correspondence to: Melissa E Crow, Brooklyn Law School One Boerum Place, Brooklyn, NY 11201,USA; mcrow65@ aol.com
$\mathrm{T}$ he international human rights regime was developed in the aftermath of the second world war to hold governments accountable for violating the rights of their citizens. The norms at the heart of this regime are embodied in numerous international treaties which obligate ratifying governments to uphold a broad spectrum of civil, political, economic, social, and cultural rights. Affirming the relevance of rights to tobacco control, the preamble to the World Health Organization's Framework Convention on Tobacco Control (FCTC) ${ }^{1}$ references the health related provisions of three of these treaties, namely the International Covenant on Economic, Social and Cultural Rights (ICESCR), the United Nations Convention on the Elimination of All Forms of Discrimination Against Women (CEDAW), and the UN Convention on the Rights of the Child (CRC). ${ }^{2}$

Treaty specific institutions promote compliance with these and other human rights treaties by reviewing governments' written reports regarding the status of their implementation efforts, often in conjunction with supplemental documentation from more objective sources including non-governmental organisations (NGOs) and UN specialised agencies. The review process may include a public session where the relevant treaty body engages in a "constructive dialogue" with government representatives on issues generated by their report. The findings and recommendations of human rights treaty bodies are conveyed to the government concerned and released publicly, as are the reports submitted by governments. By highlighting instances of noncompliance, this process is intended to impose sufficient moral pressure on recalcitrant governments to prompt better behaviour.

Some human rights treaty bodies also permit victims of human rights abuses to file complaints, known as "communications", against their governments if efforts to obtain redress at the national level have been unsuccessful or would be futile. With the exception of the European Court of Human Rights and the Inter-American Court of Human Rights, the decisions of these bodies are not legally binding. However, they have in the past prompted governments to desist from human rights violations, compensate victims, and amend legislation. ${ }^{3}$ They have also been cited with increasing frequency in the judgments of national courts.

The jurisprudence of numerous human rights treaty bodies has periodically addressed particular governments' efforts to promote tobacco control within their borders. For example, the UN Committee on Economic, Social and Cultural Rights (CESCR), which was established to promote compliance with the rights enumerated in the ICESCR, has specified in an interpretive comment that a government's failure to discourage production, marketing, and consumption of tobacco constitutes a violation of the right to health. The same comment encourages governments to undertake information campaigns regarding the adverse consequences of cigarette smoking. ${ }^{4}$ Although such comments are not legally binding, they carry considerable weight with both governments and non-governmental actors.

In the course of constructive dialogue sessions, the CESCR has questioned government representatives about the status of particular tobacco control initiatives ${ }^{5}$ and, in some cases,

\footnotetext{
Abbreviations: ATS, Alien Tort Statute; BAT, British American Tobacco; CEDAW, Convention on the Elimination of All Forms of Discrimination Against Women; CESCR, Committee on Economic, Social and Cultural Rights; CRC, Convention on the Rights of the Child; FCTC, Framework Convention on Tobacco Control; ICCPR, International Covenant on Civil and Political Rights; ICESCR, International Covenant on Economic, Social and Cultural Rights; NGOs, non-governmental organisations; UDHR, Universal Declaration of Human Rights; UN, United Nations; WHO, World Health Organization
} 
recommended measures intended to ensure that those citizens who opt to smoke are fully aware of the health risks involved. ${ }^{6}$ The UN Committee on the Elimination of Discrimination Against Women and the UN Committee on the Rights of the Child have also expressed concern about the prevalence of tobacco use in certain countries and made recommendations intended to prevent future tobacco related violations of the CEDAW and the CRC, respectively. ${ }^{7}$ While placing the onus to address tobacco related human rights abuses squarely on governments, the jurisprudence of these bodies acknowledges, at least implicitly, that the tobacco industry's conduct may precipitate human rights violations.

\section{RIGHTS RHETORIC RECONSIDERED}

NGOs have often bolstered the work of human rights treaty bodies by channelling information gathered in the course of their monitoring activities, providing technical expertise, and mobilising international public opinion. Given the receptiveness of these fora to outside interventions, tobacco control advocates should not overlook available opportunities to promote their agendas. To encourage human rights treaty bodies to consider governments' tobacco control records on more than an ad hoc basis, the tobacco control community should provide their members with accessible criteria for evaluating governmental conduct. The FCTC's detailed provisions, targeted to reduce the demand for and supply of tobacco products worldwide, provide useful benchmarks for defining governments' rights related obligations. The focus should be on the FCTC's mandatory provisions, which can be presumed to reflect the areas of broadest consensus among governments. Legal scholarship regarding the rights related implications of governments' failures to undertake particular tobacco control initiatives may also be helpful in this regard.

To give just one example, Article 13 of the FCTC prohibits tobacco advertising, promotion, and sponsorship, except to the extent permitted by a country's constitution or constitutional principles. A government's non-compliance with this prohibition could be framed as a violation of its citizens' internationally recognised rights to health, life, and freedom of information. The tobacco industry actively promotes smoking in the developing world in a variety of ways, including the use of sports and arts sponsorships, marketing techniques which deliberately target children, and deceptive advertising. ${ }^{8}$ These tactics, all of which would be prohibited by article 13 of the FCTC, have been proven to lead to increased consumption of tobacco products, a corresponding rise in tobacco related diseases and, in some cases, death. ${ }^{9}$ By failing to prohibit such tactics, governments give tobacco companies license to expand their base of consumers, who incur substantial health risks. In cases where these risks become realities, the governments' failures violate their citizens' rights to health and life. ${ }^{10}$ Insofar as the tobacco industry's unconventional promotional techniques deceive consumers about the magnitude of the health risks of tobacco use, ${ }^{11}$ governments' failures to impose adequate regulation also render them complicit in violating their citizens' rights to freedom of information. ${ }^{12}$

Having established the human rights implications of article 13 and other FCTC articles of a mandatory nature, the tobacco control community could credibly advocate for the incorporation of their requirements into relevant human rights treaty bodies' reporting guidelines. Members of these bodies could also be encouraged to address instances of noncompliance during constructive dialogue sessions with government representatives. In response to these exchanges, human rights treaty bodies would be more likely to issue country specific recommendations which regularly address tobacco related human rights violations. Where necessary, these bodies could enlist the assistance of the tobacco control community in formulating such recommendations. Tobacco control advocates could also seek to hold governments accountable for tobacco related human rights abuses by filing individual communications on behalf of sympathetic victims before treaty bodies which permit such proceedings.

In developing such strategies, the tobacco control community must bear in mind that the jurisdiction of a human rights body extends only to governments that have ratified the treaty it was established to enforce-which may or may not be the same governments that have ratified the FCTC. With respect to those governments that have ratified both the FCTC and a particular human rights treaty, the advantage of employing the relevant treaty body as a "back door" mechanism is that the FCTC's enforcement machinery is comparatively undeveloped. To the extent that particular human rights treaty bodies adopt tobacco related reporting guidelines inspired by the FCTC, ratifying governments which have not yet acceded to the FCTC could still be required to justify their failures to undertake particular tobacco control initiatives. Notably, as a party to the International Covenant on Civil and Political Rights (ICCPR), the US government is required to submit regular reports regarding its efforts to comply with the rights to life and freedom of information.

\section{THE LIMITS OF EXISTING PROHIBITIONS ON TOBACCO RELATED HUMAN RIGHTS VIOLATIONS}

While the conduct of tobacco companies is largely exempt from scrutiny by human rights treaty bodies, they have asserted their own rights with great success. In both the USA and Europe, tobacco companies have repeatedly sought to defeat advertising restrictions on grounds that they would interfere with their right to freedom of expression. ${ }^{13}$ Moreover, numerous treaties permit corporations to file claims against governments. Perhaps most notably, chapter 11 of the North American Free Trade Agreement permits corporations to initiate arbitration proceedings against foreign governments for alleged deprivations of the free trade related rights protected by that treaty. Philip Morris has reportedly considered utilising these procedures to institute proceedings against the Canadian government.

Despite a lack of oversight, the conduct of tobacco companies is the proximate cause of violations of consumers' fundamental rights. Tobacco companies may be implicated in human rights violations either directly-for example, through the types of marketing tactics discussed in the preceding section-or indirectly, through their leverage over host governments. Empirical evidence shows that comprehensive tobacco control measures, including advertising bans, warning label requirements, cigarette tax increases that keep pace with earning capacity, prohibitions on smoking in public places and workplaces, and information campaigns, reduce tobacco consumption. To protect their profits, tobacco companies actively lobby governments to prevent them from adopting such initiatives.

While many corporations employ sophisticated lobbying strategies, the duplicity of the tobacco industry is unparalleled. In Argentina, for example, Philip Morris and British American Tobacco (BAT) collaborated to achieve a presidential veto of a comprehensive advertising ban in 1992. Their joint lobbying efforts relied on data denying the existence of a link between cigarette advertising and consumption, which was generated by a project which they co-financed. ${ }^{14}$

Even the most well intentioned governments may have difficulty regulating transnational tobacco companies, whose vast resources enable them to evade restrictive national laws by shifting their operations among multiple production facilities in different countries. ${ }^{15}$ The increasing interdependence of tobacco markets, the prevalence of tobacco 
advertising leakages, and the pervasive problem of cross border tobacco smuggling in this era of globalisation further limit the potential impact of unilateral action by any country. ${ }^{16}$ Acknowledging the immense power disparity between governments and tobacco companies in many parts of the world, the FCTC preamble recognises "the need [for governments] to be alert to any efforts by the tobacco industry to undermine or subvert tobacco control efforts and the need to be informed of activities of the tobacco industry that have a negative impact on tobacco control efforts".

In an effort to address this problem, some legal scholars have made creative arguments for expanding the coverage of the existing human rights framework. Louis Henkin, for example, has construed the language of the preamble to the Universal Declaration of Human Rights (UDHR), which characterises the rights and freedoms set forth therein as "a common standard of achievement for all peoples and all nations...[including] every individual and every organ of society" to "exclud[e] no one, no company, no market, no cyberspace" ${ }^{17}$ The reference to "person" in article 30 of the UDHR could also be interpreted to encompass corporations:

\section{Nothing in this Declaration may be interpreted as implying for any State, group or person any right to engage in any activity or to perform any act aimed at the destruction of any of the rights and freedoms set forth herein.}

Although the UDHR is a UN General Assembly resolution, which does not usually create legally binding obligations, governments have tended to view it as having a normative character. $^{18}$ Moreover, many international and regional treaties, which definitively bind ratifying governments, include provisions similar to Article $30 .{ }^{19}$

Other legal scholars have made more pragmatic arguments for applying international human rights law to corporations. These arguments tend to emphasise the increasing influence of corporations over governments, which renders an exclusively government centred framework unworkable, and the consequent need for an evolving interpretation of international instruments. ${ }^{20}$

The ambiguity surrounding the appropriate scope of application of human rights treaties has led certain intergovernmental organisations, including the UN, the Organization for Economic Cooperation and Development, and the International Labor Organization, to promulgate human rights guidelines specifically for corporations. ${ }^{21}$ These guidelines generally require a corporation to respect international human rights within its "sphere of influence". In other words, the scope of a company's human rights obligations is proportional to the closeness of its relationships with victims, who would include both consumers and employees in the tobacco context, as well as other stakeholders such as government officials, indigenous peoples, lending institutions, suppliers, and trade associations. While such guidelines may indicate the prevailing expectations of many governments regarding corporate responsibility for human rights violations, the lack of any enforcement mechanism limits their utility.

As Andrew Clapham has noted, the absence of applicable enforcement procedures does not negate the existence of corporate obligations. ${ }^{22}$ Certain core human rights norms, including the prohibitions on slavery, forced labour, genocide, torture, extrajudicial murder, piracy, crimes against humanity, and apartheid, are generally viewed to apply to corporations as well as governments. ${ }^{23}$ Numerous US courts have recognised that corporations can be sued pursuant to the Alien Tort Statute (ATS) when they violate these norms, ${ }^{24}$ and international precedents dating back to the Nuremburg tribunals confirm this trend. ${ }^{25}$ The US Supreme Court recently confirmed in dicta that the ATS can be used to hold corporations liable for a narrow range of international law violations. ${ }^{26}$ To date, however, the ATS has never been used to address the tobacco industry's conduct.

\section{EMERGING NORMS ON CORPORATE RESPONSIBILITY}

In an attempt to promote greater corporate accountability for human rights violations, the UN Sub-Commission on the Promotion and Protection of Human Rights, a body of independent experts, approved a new set of "Norms on the Responsibilities of Transnational Corporations and Other Business Enterprises with Regard to Human Rights" ("Norms") on 13 August 2003. ${ }^{27}$ While emphasising that the Norms did not have legal standing, the UN Commission on Human Rights confirmed their "importance and priority" in April 2004 and asked the Office of the UN High Commissioner for Human Rights to conduct further research and report on "options for strengthening standards... and possible means for their implementation" before the Commission's next session. ${ }^{28}$ At its 2005 session, the Commission adopted a resolution welcoming the report and called for the UN Secretary-General to appoint a Special Rapporteur on human rights, transnational corporations, and other business entities. ${ }^{29}$

The Norms are ultimately intended to impose binding human rights obligations on private business entities. During the drafting process, governments, intergovernmental organisations, NGOs, unions, multinational corporations, and other business enterprises were asked to provide input. ${ }^{30}$ While emphasising that governments still bear primary responsibility for the protection of human rights, the Norms impose obligations on transnational corporations and other business enterprises "[w]ithin their respective spheres of activity and influence...to promote, secure the fulfillment of, respect, ensure respect of and protect human rights recognized in international as well as national law" (article 1). The far reaching influence of the tobacco industry in many parts of the developing world may make the "spheres of activity and influence" qualification irrelevant in practice.

For purposes of tobacco control, relevant Norms include those protecting the rights to the highest attainable standard of physical and mental health (article 12) and a safe and healthy working environment (article 7). However, the most path-forging section of the Norms is article 13, which addresses the obligations of businesses regarding consumer protection:

13. Transnational corporations and other business enterprises shall act in accordance with fair business, marketing and advertising practices and shall take all necessary steps to ensure the safety and quality of the goods and services they provide, including observance of the precautionary principle. Nor shall they produce, distribute, market, or advertise harmful or potentially harmful products for use by consumers.

The accompanying commentary provides, in relevant part:

(b) Transnational corporations and other business enterprises shall observe relevant international standards for the protection of consumers.... Transnational corporations and other business enterprises shall ensure that all marketing claims are independently verifiable, satisfy reasonable and relevant legal levels of truthfulness, and 
are not misleading. Further, they shall not target children when advertising potentially harmful products.

(c) Transnational corporations and other business enterprises shall ensure that all goods and services they produce, distribute, or market are...safe for intended and reasonably foreseeable uses, do not endanger the life or health of consumers, and are regularly monitored and tested to ensure compliance with these standards, in the context of reasonable usage and custom. They shall adhere to relevant international standards so as to avoid variations in the quality of products that would have detrimental effects on consumers, especially in States lacking specific regulations on product quality....

(e) ...[W] here a product is potentially harmful to the consumer, transnational corporations and other business enterprises shall disclose all appropriate information on the contents and possible hazardous effects of the products they produce through proper labeling, informative and accurate advertising and other appropriate methods. In particular, they shall warn if death or serious injury is probable from a defect, use, or misuse. Transnational corporations and other business enterprises shall supply appropriate information of potentially harmful products to the relevant authorities....

These expansive provisions raise the question of whether tobacco companies can ever comply fully with the Norms given the addictive and potentially deadly nature of the products they sell. However, if the Norms actually required a de facto ban on tobacco products, the tobacco industry would reject them completely. This result would undermine the goals of the drafters, who integrated multinational corporations into the drafting process in the hope that they would ultimately agree to be bound by the Norms. It is thus reasonable to assume that the health risks inherent in using tobacco products do not preclude the entire tobacco industry from conducting business in conformity with the Norms. At a minimum, the Norms would require effective warning labels on cigarette packages, preclude deceptive promotional practices, and prohibit advertising targeting children and other vulnerable groups.

The Norms have considerable potential for preventing human rights violations by multinational corporations, including tobacco companies. Their non-voluntary character is bolstered by the inclusion of enforcement provisions. The Norms anticipate that companies' compliance will be monitored by the UN and "other international and national mechanisms already in existence or yet to be created", with input from NGOs and other relevant stakeholders (article 16). In cases where the monitoring process reveals that a company's failure to comply with the Norms has resulted in harm to an individual, entity or community, the company may be required to pay reparations (article 18). Governments are also expected to promulgate laws and regulations conducive to the implementation of the Norms (article 17).

There is currently no consensus within the international community on the authoritativeness of the Norms. Adoption of the Norms by the UN Commission on Human Rights would bolster their credibility considerably.

\section{ADDITIONAL STRATEGIES FOR ENFORCING THE HUMAN RIGHTS RESPONSIBILITIES OF MULTINATIONAL TOBACCO COMPANIES}

Even before the Norms become binding international law, they could help to promote greater accountability on the part of the tobacco industry for its role in human rights violations. As the commentary to article 16 suggests, NGOs could use the Norms as a basis for their monitoring activities. To date, only

\section{What this paper adds}

The existing international human rights regime, which is embodied in numerous treaties, obligates governments to protect the rights of their citizens. The norms at the heart of this regime are enforced by treaty specific institutions, which have periodically issued jurisprudence characterising governments' failures to undertake particular tobacco control initiatives as rights violations. This article adds to the existing literature by delineating how tobacco control advocates could utilize the Framework Convention on Tobacco Control to promote more systematic consideration of tobacco related human rights violations. It also proposes and evaluates various strategies for holding tobacco companies directly accountable for human rights violations.

a few NGOs have scrutinised the activities of the tobacco industry, and their reports have focused primarily on violations of workers' rights. In 2002, for example, the British Helsinki Human Rights Group reported that BAT was subjecting local Uzbek tobacco farmers to slave labour. ${ }^{31}$ Christian Aid has published similarly damning reports regarding the apparent indifference of BAT's subsidiaries in Brazil and Kenya to the welfare of the tobacco farmers they employ. ${ }^{32}$

While these organisations should be commended for highlighting the deplorable working conditions that tobacco industry employees in the developing world are often forced to endure, their monitoring activities should be expanded to encompass the types of consumer rights violations embodied in the Norms, including the deceptive tactics that the tobacco industry utilises to market and distribute an addictive, and potentially deadly, product. Past experience has demonstrated the impact of such efforts to generate greater public awareness about particular companies' direct and indirect violations of individual rights. ${ }^{33}$

Meanwhile, tobacco control advocates should employ the strategies discussed above (in the section on rights rhetoric reconsidered) to generate greater awareness of tobacco related human rights violations by governments and, where possible, to highlight the complicity of the tobacco industry in these violations. As indicated in the commentary to article 16, the Norms could serve as the basis for developing additional guidelines for governments' reports to human rights treaty bodies. The input of the tobacco control community could be instrumental in facilitating this endeavour. In addition to clarifying the evolving responsibilities of corporations, such requirements would make it politically easier for governments to acknowledge the ways in which the tobacco industry's tactics have obstructed their efforts to protect their citizens' rights. ${ }^{34}$ They could also promote increased information sharing and collaboration among governments which have confronted similar obstacles.

Given the lack of any centralised enforcement mechanism for promoting corporate compliance with existing and emerging human rights norms, the process of enforcement must necessarily involve a broad spectrum of actors. In particular, the tobacco control community should strive to educate constituencies with greater leverage over the tobacco industry-including tobacco industry shareholders, employees, and consumers-about acceptable standards of corporate conduct. It is my hope that this article will facilitate such efforts and help to ensure that tobacco companies start to take their human rights responsibilities seriously. 


\section{ACKNOWLEDGEMENTS}

The author is deeply indebted to Jonathan Liberman for his impeccable insights and meticulous editing, and to Ariana DrusineStokes for her research assistance.

Competing interests: none declared

\section{REFERENCES}

1 World Health Organization. Final version, WHO Framework Convention on Tobacco Control, hitp://www. who.int/tobacco/fctc/text/en/fctc_en.pdf. The FCTC entered into force on 27 February 2005. As of this writing, 58 governments have ratified it, and 168 governments have signed it.

2 The language of rights is conspicuously absent from the rest of the FCTC. This omission may be attributable to a variety of factors, including the lack of rights-based expertise among the entities and individuals involved in the negotiations, the public health community's relative unfamiliarity with international human rights law, the controversial status of the right to health under international law, and many governments' competing concerns about retaining certain sovereign rights. Telephone Interview with Allyn Taylor, Adjunct Professor, University of Maryland Law School, Former Senior Legal Adviser to WHO Tobacco Free Initiative (Aug. 19, 2003). The U.S. negotiating team in particular was adamant about excluding rights-based language from the FCTC. Email from Thomas E Novotny, MD MPH, to author (26 Feb 2005) (on file with author).

3 Evatt E. The right to individual petition: assessing its operation before the Human Rights Committee and its future application to the Women's Convention on Discrimination. American Society of International Law Proceedings 1995;29:229.

4 UN Committee on Economic, Social and Cultural Rights. General Comment 14-The Right to the Highest Attainable Standard of Health, 22d Sess. paras. 15, 51, UN Doc. E/C.12/2000/4 (2000).

5 UN Committee on Economic, Social and Cultural Rights. Summary Records, 22d Sess., 8th mtg., UN Doc. E/C.12/2000/SR.8 (discussing Italy's antismoking campaigns and justification for advertising Marlboro tobacco brand on Ferrari cars in Formula One racing competition, which was broadcast widely on Italian television, in light of tobacco advertising ban); UN Committee on Economic Social and Cultural Rights. Summary Records, 20th Sess., 16th mtg., UN Doc. E/C.12/1999/SR. 16 (1999) (discussing Ireland's willingness to comply with WHO guidelines calling for increased taxes on tobacco products and implementation of a total advertising ban).

6 UN Committee on Economic, Social and Cultural Rights. Concluding Observations of the Committee on Economic, Social and Cultural Rights: Ukraine, 26th Sess., UN Doc. E/C.12/1/Add. 65 (2001) (recommending that the Ukrainian government provide children with accurate and objective information about tobacco use and discourage public mass media from promoting consumption of tobacco products); UN Committee on Economic Social and Cultural Rights, Concluding Observations of the Committee on Economic, Social and Cultural Rights: Poland, 18th Sess., 26th mtg., UN Doc. E/C. 12/1/Add. 26 (1998) (recommending that the Polish government engage in a large-scale public information campaign to combat smoking)

7 UN General Assembly Official Records. Report of the Committee on the Elimination of Discrimination Against Women: Kazakhstan, 24th Sess., para. 105, UN Doc. A/56/38 (2001) (expressing concern about the status of women's health, including their increasing use of tobacco); UN Committee on the Rights of the Child, Concluding Observations of the Committee on the Rights of the Child: South Africa, 23d Sess., 615th mtg., UN Doc. CRC/C/ 15/Add. 122 (2000) (expressing concern about the limited availability of programs, services, and the lack of adequate data in the area of adolescent health, including tobacco use); UN Committee on the Rights of the Child, Concluding Observations of the Committee on the Rights of the Child: Armenia, 23d Sess., para. 53, U. N. Doc. CRC/C/15/Add. 110 (2000) (encouraging the State Party to continue its efforts to provide children with accurate and objective information about tobacco use and to protect them from harmful misinformation by imposing comprehensive restrictions on tobacco advertising).

8 Liberman J, Clough J. Corporations that kill: the criminal liability of tobacco manufacturers. Criminal Law Journal 2002;26:1-12.

9 WHO Expert Committee on Smoking Control. Controlling the smoking epidemic, 1979, WHO Technical Report Series No. 636 (reporting that the tobacco industry's marketing tactics cause a significant number of unnecessary deaths); UK Department of Health. Effect of tobacco advertising on tobacco consumption: a discussion document reviewing the evidence, 1992, para. 69 lasserting that the balance of evidence supports the conclusion that advertising has a positive effect on the consumption of tobacco products)

10 Appleberry R. Breaking the camel's back: bringing women's human rights to bear on tobacco control. Yale Journal of Law and Feminism 2001;13:84-88; Wike J, The Marlboro Man in Asia: U. S. tobacco and human rights. Vanderbilt Journal of Transnational Law 1996;29: 351-52; Crow M. Smokescreens and state responsibility: using human rights strategies to promote global tobacco control. Yale Journal of International Law 2004;29:225-45

11 Working Group of the WHO Framework Convention on Tobacco Control. Economics of Tobacco Control, $1^{\text {st }} \mathrm{mtg}$., WHO Doc. A/FCTC/WGI/2 (1999), http://www.who.int/gb/fctc/PDF/wgl/elt2 pdf, at 4 (noting that sixty-one percent of smokers surveyed in China in 1996 believed that tobacco caused "little or no harm").

12 Dhooge L. Smoke across the waters: tobacco production and exportation as international human rights violations. Fordham International Law Journal
1998;22:431-5; Mann J, Gostin L, Gruskin S, et al. Health and human rights. In: Mann J, Gruskin S, Grodin M, et al, eds. Health and human rights, New York: Routledge, 1999: 15; Kozlowski L. Harm reduction, public health, and human rights: smokers have a right to be informed of significant harm reduction options. Nicotine Tob Res 2002;4:55-60.

13 Lorillard Tobacco Co. v. Reilly, 84 F.Supp.2d 180 (D. Mass. 2000), (rejecting claims by Lorillard Tobacco Company, R.J. Reynolds Tobacco Company, Philip Morris Incorporated, Brown \& Williamson Tobacco Corporation, and United States Tobacco Company that Massachusetts' proposed tobacco product advertising and promotion regulations violated the First Amendment, with the exception of point-of-sale regulations), Bitton A, Neuman M, Glantz $\mathrm{S}$, Tobacco industry attempts to subvert European Union tobacco advertising legislation. Center for Tobacco Control Research and Education, University of California, EU Paper 2002, http://repositories.cdlib.org/ctcre/tcpmi/ EU2002 (summarizing the tobacco industry's efforts to defeat a proposed European advertising ban based in part on right to freedom of expression).

14 Pan-American Health Organization. Profits over people: tobacco industry activities to market cigarettes and undermine public health in Latin America and the Caribbean, 2002, http://www.paho.org/English/HPP/HPM/TOH/ profits_over_people, pdf. 26,41-4.

15 Grossman C, Bradlow D. Are we being propelled towards a people-centered transnational legal order? American University Journal of International Law and Policy 1993;9:8.

16 Sugarman S. International aspects of tobacco control and the proposed WHO treaty. In. Rabin R, Sugarman S, eds. Regulating tobacco. New York: Oxford University Press, 2001:249-59.

17 Henkin L. The universal declaration at 50 and the challenge of global markets. Brooklyn Journal of International Law 1999;25:25.

18 International Council on Human Rights Policy. Beyond voluntarism: human rights and the developing international legal obligations of companies, 2002, http://www.ichrp.org/excerpts/30.pdf. 58-62.

19 Paust J. Human rights responsibilities of private corporations. Vanderbilt Journal of Transnational Law 2002;35:811-19.

20 Ratner S. Corporations and human rights: a theory of legal responsibility. Yale Journal of International Law 2001;111:464-65; Clapham A. Human rights in the private sphere. New York: Oxford University Press, 1993:98-9.

21 UN Global Compact. http://www.unglobalcompact.org/Portal/default. asp? NavigationTarget = /roles/portal_user/aboutTheGC/nf/nf/ theNinePrinciples; OECD Guidelines for Multinational Enterprises, http:// www.oecd.org/document/28/0,2340,en_2649_34889 2397532 _1_1_1_1,00 html; ILO Tripartite Declaration of Principles Concerning Multinational Enterprises, http://www.ilo.org/public/english/standards/ norm/sources/mnehtm.

22 Clapham A. The question of jurisdiction under international criminal law over legal persons. In: Kamminga M, Zia-Zarifi S, eds. Liability of multinational corporations under international law. Boston, Massachusetts: Kluwer Law International, 2000:193

23 Kamminga $M$, Zia-Zarifis S. Liability of multinational corporations under international law: an introduction. In: Kamminga M, Zia-Zarifi S, eds. Liability of multinational corporations under international law. Boston, Massachusetts: Kluwer Law International, 2000:8-9.

24 Presbyterian Church of Sudan v. Talisman Energy, Inc. 244 F. Supp. 2d 289, 308-15 (SDNY 2003) (reviewing ATS precedent from various U.S. circuit and district courts).

25 Stephens B. The amorality of profit: transnational corporations and human rights, Berkeley Journal of International Law 2002;20:76-7.

26 Sosa v. Alvarez-Machain, 124 S.Ct. 2739, 2766 n. 20 (2004)

27 UN Sub-Commission on the Promotion and Protection of Human Rights, Responsibilities of Transnational Corporations and Other Business Enterprises with Regard to Human Rights, Resolution 2003/16, UN Doc. E/CN.4/Sub.2/ 2003/L. 11, at 52 (2003), http://wwwl .umn.edu/humanrts/links/res200316.html.

28 UN Economic and Social Council Official Records, 60th Sess., Agenda Item 21 (b), UN Doc. E/CN.4/2004/L.11/Add.7 (2004); UN Commission on Human Rights, Responsibilities of Transnational Corporations and Related Business Enterprises with Regard to Human Rights, Decision 2004/116, UN Doc. E/CNY/2004/L.11/Add.7, paras. (a) and (b).

29 Weissbrodt D. E-mail from David Weissbrodt, Professor, University of Minnesota Law School, to author (13 May 2005) (on file with author).

30 UN Sub-Commission on Human Rights. The Relationship Between the Enjoyment of Economic, Social and Cultural Rights and the Right to Development, and the Working Methods and Activities of Transnational Corporations, UN Doc. E/CN.4/Sub.2/RES/2002/8; UN Sub-Commission on Human Rights, Report of the Sessional Working Group on the Working Methods and Activities of Transnational Corporations, UN Doc. E/CN.4/ Sub. $2 / 2003 / 13$

31 British Helsinki Human Rights Group. B.A.T. in Uzbekistan, 2002, http:// www.bhhrg.org/CountryReport.asp?CountryID = 23.

32 Christian Aid. Hooked on tobacco. UK: Christian Aid, 2002, http:// www.christian-aid.org.uk/indepth/0201 bat/index.htm; Christian Aid, Behind the mask: the real face of corporate social responsibility. UK: Christian Aid, 2004, http://www.christian-aid.org.uk/indepth/0401csr/ crs_behindthemask.pdf.

33 Zelman N. The Nestle infant formula controversy: restricting the marketing practices of multinational corporations in the third world. Transnational Law 1990;3:722-3

34 Weissbrodt W, Kruger M. Norms on the responsibilities of transnational corporations and other business enterprises with regard to human rights. American Journal of International Law 2003;97:917, 921-2. 